\title{
Relationship between physical activity and depression according to the presence of disease in koreans over the Age of 40
}

\author{
Jung-woon Kim¹, Joon-sik Kim¹, Jung-jun Lim¹, Yeon-soo Kim*, \\ On $\mathrm{Lee}^{2}$, Bo-youl Choi ${ }^{3}$, \& Mi-kyung $\mathrm{Kim}^{3}$ \\ ${ }^{1}$ Seoul National University, ${ }^{2}$ Korea Institute of Sports Science, \& ${ }^{3}$ Hanyang University
}

\begin{abstract}
[Purpose] The purpose of this study was to investigate the relationship between physical activity and depression according to the presence of disease. [Methods] A survey and basic assessment were conducted for 2,754 (Male=1,025 and Female=1,729) aged 40 and over who participated in the rural-based cohort study. The survey included physical activity, depression scale and disease preservation. The basic assessment measured height, weight, and body fat percentage. The measured data were analyzed by using logistic regression to examine the relationship between physical activity and depression prevalence. [Results] First, physical activity reduced the prevalence of depression by $33 \%$ and 51\%, respectively, in the general population and in patients with the disease. Second, physical activity once or twice per week reduced the prevalence of depression in patients with disease by $51 \%$, and at least three physical activities reduced the prevalence of depression by $37 \%$ in the general population and $33 \%$ of patients with disease. Third, physical activity less than 150 minutes per week reduced the prevalence of depression in patients with disease by $43 \%$, and physical activity of more than 150 minutes and less than 300 minutes per week reduced the prevalence of $43 \%$ of the general population and $52 \%$ of patients with disease. Physical activity over 300 minutes per week had a $38 \%$ reduction in the prevalence of depression in the general population. [Conclusion] This study suggests that the level of physical activity suggested by the ACSM guidelines is appropriate to reduce the prevalence of depression. In addition, the patients with the disease was found to be effective with less frequency and amount of physical activity than the general person.
\end{abstract}

Key Words: Physical activity, Depression, Disease

\section{서 론}

우울증은 전 세계적으로 3 억 명 이상의 사람들이 겪는 건강 문제로 모든 사망원인의 $12.7 \%$ 를 차지하고 있는 질 병이며 환자수가 점차 증가하고 있다(Walker et al.,

논문 투고일 : 2019. 11. 05.

논문 수정일 : 2019. 11. 29.

게재 확정일 : 2019. 12. 15.

* 교신저자 : 김연수( $\mathrm{kys} 0101 @ \mathrm{snu} . \mathrm{ac} . \mathrm{kr})$.
2015). 우울증은 식욕 저하, 수면 장애, 무력감, 자살 충 동 및 시도 등 다양한 형태의 신체적·인지적 문제를 발생 시키며(Isacsson et al., 2010), 이로 인해 우울증 환자 는 일반사람에 비해 평균수명이 5년 10년 짧다(Katon, 2011).

세계적 흐름과 동일하게 대한민국도 우울증 환자가 매 해 증가하고 있으며, 의료비 지출도 점차 늘어나고 있다. 또한, 통계청(2019)은 2018년 한국인 사망원인통계에 
서 우울증의 가장 대표적인 문제인 자살이 사망률 5 위로 집계되었으며, 26.6 명/10만의 사망자가 발생하고 있음 을 보고하고 있어 우울증이 개인의 차원을 넘어 사회적으 로 관리가 되어야 하는 질병으로 인식되고 있다.

우울증을 발생시키는 위험요인으로는 성별, 연령, 음 주, 흡연, 비만, 질병 등이 보고되고 있다(Wang et al., 2019). 이 중 질병은 신체적인 고통을 유발하여 행동에 제약을 발생시킴으로써 개인의 자존감 및 삶의 질을 저하 시켜 우울증을 발생시킨다. 따라서 암, 심장질환, 당뇨, 호흡기질환 등의 질병을 가진 환자는 일반사람들에 비해 우울증에 걸릴 확률이 2 3배 높아(Nan et al., 2012), 질병 치료 과정에서 우울증 관리가 필수적으로 이루어져 야 한다. 반대로 우울증은 심장질환, 당뇨, 호흡기질환 등 과 같은 여러 질병을 발생시키기도 한다(Mezuk et al., 2008). 이는 우울증으로 인한 인체의 비정상적인 호르몬 분비와 생리적 리듬에 문제가 발생하여 건강한 생활습관 을 유지할 수 없기 때문이다(Kennedy et al., 1991). 따 라서, 우울증 관리는 질병을 예방하고 치료하는데 중요한 의학적 고려요소이다. 우울증은 자체적인 문제와 더불어 질병의 발생 및 악화 등의 문제를 발생시키기 때문에 반 드시 관리가 필요한 대상으로 인식되고 있으며, 확실한 예방과 치료방법을 찾기 위해 다양한 연구가 수행되고 있다.

현재 선행연구에서 대표적인 우울증 예방 및 치료는 항우울제를 처방하는 약물요법과 심리치료다. 항우울제 는 선택적으로 세로토닌(Serotonin) 재흡수를 억제하여 우울증을 관리하는 방법으로 항우울 효과는 있지만, 복용 한 사람의 $50 \%$ 에서만 통계적으로 유의하게 우울증상이 감소하였다고 보고되었다(Allan \& Ebmeier, 2018). 또 한, 선행연구에서는 약물 복용 유지의 어려움과 더불어 체중과 당뇨병 위험 증가, 성기능 장애 및 각종 질병 발생 으로 인해 사망률 증가의 부작용이 보고되고 있다 (Cipriani et al., 2018). 인지 행동 치료와 같은 심리치 료는 우울증 감소에 중소의 효과가 보고되고 있으나 (Cuijpers et al., 2014), 실시 가능한 대상의 한계점을 보였다. 장시간 앉아있거나 대화를 할 수 없을 정도의 건 강이 좋지 않은 사람에게는 실시할 수 없었으며, 우울증 으로 인해 심신이 약해진 환자에게 타인과 상호작용을 해 야 하는 심리치료는 일부 두려움의 대상이 되었다. 따라
서, 이러한 방법들의 단점을 보완할 수 있는 대체적인 방 법의 필요성이 꾸준히 제기되었다.

신체활동 및 운동은 실천유무, 빈도, 수행 시간 등에 따라 우울증에 영향을 줄 수 있는 것으로 알려져 있다. 실 제로 미스포츠의학회(American College of Sports Medicine, ACSM)과 세계보건기구(World Health Organization, $\mathrm{WHO}$ )에서는 연령별 또는 일부 질병에 따른 신체활동 가이드라인을 제시하여 신체 및 정신건강 의 증진에 힘쓰고 있다.

하지만, 우울증의 예방 및 치료를 위한 신체활동 가이 드라인은 연구 및 데이터 부족으로 지금까지 제시되지 못 하고 있다. 현재도 가이드라인 제시를 위한 많은 연구가 지속적으로 수행되고 있지만, 일치된 결론을 도출하지 못 하고 있다. Williams \& Lord(1997)는 우울증 진단을 받 은 374 명의 60 세 이상 성인을 대상으로 주 2 회, 120 분의 신체활동을 실시한 결과, 우울증에 긍정적인 영향을 미친 다는 결론을 도출한 반면, Underwood et al.(2013)은 우울증이 있는 65세 이상 노인 891명을 대상으로 가정기 반 운동 중재를 실시한 결과, 운동이 우울증상을 완화하 지 못했다는 결론을 도출하였다. 일반사람들이 아닌 질병 을 가진 환자를 대상으로 진행한 연구에서도 신체활동의 효과에 대한 상이한 결과를 보고하고 있다. 질병을 가진 환자들에게 신체활동이 우울증에 긍정적인 효과가 있다 는 review 논문이 보고된 반면(Felipe \& Brendon, 2019), 242명의 심혈관 질환을 가진 환자를 대상으로 실 시한 연구에서는 주당 $336 \mathrm{kcal}$ 이상의 신체활동이 심혈 관 질환의 사망률은 낮추었으나, 우울증상 및 복합질환 발생에는 악영향을 미쳤다는 결과를 보고한 연구도 있었 다(Peterson et al., 2014). 선행연구에서 상이한 결과 가 도출된 것은 연구대상자의 특성에 따라 우울증을 경감 시키는 적절한 신체활동 빈도와 시간이 있음을 시사하고 있다. 즉, 일반사람과 질병을 가진 환자는 같은 빈도와 시 간의 신체활동을 수행해도 다른 효과가 나타날 수 있다.

따라서 본 연구에서는 질병 유무에 따른 신체활동과 우울증의 관계를 알아보고, 일반사람과 질병을 가진 환자 집단에서 우울증에 가장 큰 영향을 줄 수 있는 신체활동 빈도와 시간을 찾고자 한다. 


\section{연구방법}

\section{연구대상 및 자료수집 방법}

본 연구는 질병관리본부에서 주관하는 한국인 유전체 역학조사사업 중 농촌기반 코호트사업을 진행한 경기도 $\mathrm{OO}$ 시에 거주하는 40세 이상 남녀를 대상으로 하였다. 본 연구는 2007년부터 2013년도까지 연구참여자를 모집하 였으며 총 3,719 명 중 우울증 설문에 응답하지 않은 965 명을 제외한 2,754 명 (남 1,025 명, 여 1,729명)을 최종 대상자로 선정하였다. 모든 연구참여자는 연구의 목적과 내용에 대한 설명을 들은 후 자발적으로 동의한 자로 한 정하였다. 본 연구에 사용된 자료는 대부분 일대일 대면 설문조사 방식으로 획득하였으며, 사전에 설문 및 설문지 에 대해 교육을 받은 전문 면접원에 의해 설문을 진행하 였다. 면접이 어려운 연구대상자는 대리인 설문 등의 표 준화된 절차와 방법에 의해 설문을 실시하여 자료를 수집 하였다. 본 연구는 H대학교 임상시험 심의위원회의 승인 을 받고 진행되었다.

\section{연구항목 및 방법}

\section{신체활동 설문}

신체활동 실천 유무

본 연구에서는 신체활동 실천 유무를 알아보기 위해 "땀이 몸에 베일 정도의 신체활동을 규칙적으로 하십니 까?"라는 설문을 실시하였으며, “(1) 안 한다 (2) 한다”의 응 답을 이용하여 2 개 그룹으로 분류하였다.

주당 신체활동 빈도

신체활동 실천 유무에 “(2) 한다”라고 응답한 사람들을 대상으로 신체활동 빈도를 조사하기 위해 "신체활동을 하신 다면 일주일에 몇 회 정도 하십니까?”라는 설문을 하였 으며, “(1) 1 회 2회 (2) 3회 4회 (3) 5 회 6회 (4) 거의 매일”의 응답을 받았다. ACSM 가이드라인에 근거하여 “0회, 1 회 2 회, 3 회 이상”의 3 개 그룹으로 분류하였다.

주당 신체활동 시간

주당 신체활동 시간을 조사하기 위해 "한번 할 때 평균
몇 분 정도 신체활동을 하십니까?"의 설문을 실시하였으 며, 연구참여자가 응답한 시간에 주당 평균 신체활동 빈도 를 곱하여 주당 신체활동 시간을 산출하였다. 산출된 시간 을 근거로 “주당 신체활동 시간 0 분, 1 분 149 분, 150 분 299분, 300 분 이상”의 4 개 그룹으로 분류하였다.

\section{우울증 척도 검사(Korean version of Center for Epidemiologic Studies Depression Scale, K-CESD)}

우울증 척도 검사는 Radloff(1977)가 개발한 CESD 검사지로 Cho \& Kim(1993)이 번역하여 신뢰도와 타당 도를 입증한 한국어판 $\mathrm{K}-\mathrm{CESD}$ 설문지를 사용하여 조사 하였다. $\mathrm{K}-\mathrm{CESD}$ 는 자가보고형 우울증상 설문지로, 문 항이 매우 간결하고 증상의 존재 기간을 기준으로 심각도 를 측정하기 때문에 역학 연구에 널리 사용된다. 임상적 인 우울증 진단 도구는 아니지만 우울증상을 잘 반영하여 유병률을 비교·분석하는데 폭넓게 사용되고 있다. $\mathrm{K}-\mathrm{CESD}$ 는 20문항으로 구성되어져 있으며, 각 항목은 0 점에서 3점으로 채점되어 총점 범위는 0점부터 60점까지 이다. 부정문인 5 번, 10 번, 15 번, 20 번 문항은 역코딩 하 였으며, 총점이 높을수록 우울증 확률이 높은 것을 의미한 다. $\mathrm{K}-\mathrm{CESD}$ 의 우울증 절단점은 총점 16 점과 25 점을 많이 사용하는데, 16점은 유력우울증(Probable depression), 25점은 확실우울증(Definite depression)을 의미한다. 본 연구에서는 16 점을 절단점으로 이상이면 우울증 있는 그룹으로, 미만이면 우울증이 없는 그룹으로 분류하였다.

\section{기초평가 및 질병 보유 검사}

기초평가 중 인구통계학적 정보, 생활습관 등은 $1: 1$ 대면설문을 통해 조사하였다. 신장, 체중과 신체조성은 Inbody 3.0(Biospace, Korea)을 이용하여 측정하였다. 설문을 통해 연구참여자의 질병 유무를 조사하였으며, 설 문 당시 만성질환인 고혈압, 고지혈증, 당뇨와 사망률이 높은 질환인 심장질환, 뇌혈관질환 및 각종 암을 가진 참 여자를 질병 그룹으로 정의하였다.

\section{자료처리 방법}

본 연구에서 획득한 모든 데이터는 Window용 SPSS 
ver 23.0 을 이용하여 분석하였다. 연구참여자의 일반적 특성을 기술통계를 통해 표시하였으며, 일반인 그룹과 질 병을 가진 그룹의 일반적 특성 비교를 위해 독립표본 $\mathrm{t}$ 검 증(Independent t-test)을 사용하였다. 질병 유무에 따 른 신체활동과 우울증의 관계를 분석하기 위해 로지스틱 회귀분석(Logistic regression)을 실시하여 위험비(odds ratio)와 95\%신뢰구간(Confidence interval, CI)을 산 출하였다. 분석 과정에서 신체활동과 우울증의 관계에 영 향을 줄 수 있는 성별, 연령, 음주, 흡연, 결혼상태, 학력, 체질량지수(Body Mass Index, BMI)가 보정변수로 사 용되었다. 모든 통계적 유의수준 $(\alpha)$ 은 .05로 설정하였다.

\section{연구결과}

\section{연구대상자의 특성}

본 연구는 경기도 $\mathrm{OO}$ 시에 거주하는 40세 이상 성인 남, 여 2,754명 (남 1,025 명, 여 1,729 명)의 자료를 분석
하였으며, 연구참여자의 특성은 〈Table 1)과 같다. 평균 연령은 $62.0 \pm 10.6$ 세이며, 신장 $157.6 \pm 8.5 \mathrm{~cm}$, 체중 $60.9 \pm 10.1 \mathrm{~kg}$ 으로 나타났다. 경기도 $\mathrm{OO}$ 시의 40 세 이상 성인 남녀의 전체 우울증 유병률은 305명 (11.1\%)로 나 타났으며, 질병을 가진 환자의 우울증 유병률 $(15.2 \%)$ 이 일반사람의 우울증 유병률 $(9.1 \%)$ 보다 $6.1 \%$ 높았다. 비 만지수를 나타내는 체질량지수, 체지방률과 허리 둘레는 질병을 가진 환자 그룹이 일반인 그룹에 비해 통계적으로 유의하게 높은 결과를 나타냈다. 생활습관인 음주 및 흡 연 실태를 조사한 결과, 일반인 그룹의 음주율은 $53.6 \%$, 흡연율은 $29.7 \%$ 로 조사되었으며, 질병을 가진 환자 그 룹의 음주율은 $59.4 \%$, 흡연율은 $36.8 \%$ 로 조사되어 질 병을 가진 환자 그룹에서 음주 및 흡연율이 높은 것으로 나타났다.

\section{신체활동, 우울증, 질병유무의 성별과 연령 분포}

신체활동, 우울증, 질병유무의 성별과 연령 분포는 〈Table 2〉와 같다. 연구참여자의 $37.2 \%$ 는 남성이었으

Table 1. Characteristics of participants

\begin{tabular}{|c|c|c|c|c|}
\hline Characteristic & $\begin{array}{c}\text { Total } \\
(\mathrm{N}=2,754)\end{array}$ & $\begin{array}{l}\text { Without major chronic disease } \\
\qquad(\mathrm{N}=1,874)\end{array}$ & $\begin{array}{l}\text { With major chronic disease } \\
\qquad(\mathrm{N}=880)\end{array}$ & $\mathrm{p}$ \\
\hline Female (n, \%) & $1,729(62.8)$ & $1,169(62.4)$ & $560(63.6)$ & \\
\hline Age (yr) & $62.0 \pm 10.6$ & $61.0 \pm 11.0$ & $64.2 \pm 9.2$ & $<.001$ \\
\hline Height $(\mathrm{cm})$ & $157.6 \pm 8.5$ & $157.9 \pm 8.6$ & $156.9 \pm 8.4$ & .004 \\
\hline Weight (kg) & $60.9 \pm 10.1$ & $60.4 \pm 9.9$ & $62.1 \pm 10.3$ & $<.001$ \\
\hline Body Mass Index $\left(\mathrm{kg} / \mathrm{m}^{2}\right)$ & $24.5 \pm 3.2$ & $24.2 \pm 3.1$ & $25.1 \pm 3.3$ & $<.001$ \\
\hline$\%$ Body fat $(\%)$ & $27.9 \pm 9.9$ & $27.3 \pm 10.2$ & $29.2 \pm 9.1$ & $<.001$ \\
\hline Waist circumference $(\mathrm{cm})$ & $85.8 \pm 40.0$ & $84.2 \pm 31.2$ & $89.4 \pm 54.0$ & .008 \\
\hline $\mathrm{SBP}(\mathrm{mmHg})$ & $123.8 \pm 40.6$ & $121.9 \pm 43.3$ & $127.9 \pm 33.6$ & $<.001$ \\
\hline $\mathrm{DBP}(\mathrm{mmHg})$ & $76.8 \pm 40.6$ & $76.7 \pm 43.8$ & $77.0 \pm 32.8$ & .810 \\
\hline $\mathrm{TC}(\mathrm{mg} / \mathrm{dl})$ & $194.8 \pm 35.8$ & $195.6 \pm 34.6$ & $193.0 \pm 38.1$ & .075 \\
\hline Glucose & $103.1 \pm 23.1$ & $99.9 \pm 19.6$ & $109.8 \pm 28.2$ & $<.001$ \\
\hline K-CESD score & $6.1 \pm 8.4$ & $5.7 \pm 8.1$ & $6.9 \pm 9.0$ & $<.001$ \\
\hline Prevalence of depression (n, \%) & $305(11.1)$ & $171(9.1)$ & $134(15.2)$ & \\
\hline Alcohol (n, \%) & $1,527(55.4)$ & $1,004(53.6)$ & $523(59.4)$ & \\
\hline Smoking (n, \%) & $880(31.9)$ & $556(29.7)$ & $324(36.8)$ & \\
\hline
\end{tabular}

SBP, Systolic Blood Pressure; DBP, Diastolic Blood Pressure; TC, total cholesterol; K-CESD, Korean version of Center for Epidemiologic Studies Depression Scale 
며, 성별에서 65 세 이상 노인의 비율은 남성이 $51.9 \%$, 여성이 $42.0 \%$ 로 나타났다. 신체활동은 연구참여자의 $34.5 \%$ 가 실시하였으며, 남녀 모두에서 대부분 주 150 분 이상 신체활동에 참여하였으며, 남성은 주 300 분 이상의 신체활동에 참여한 사람의 비율이 높았다. 특히, 남성이 여성보다 신체활동에 참여하는 65 세 이상 노인의 비율이 높은 것으로 나타났다. 우울증이 있는 사람은 연구참여자 의 $11.1 \%$ 로, 남성 중 $5.1 \%$, 여성 중 $14.6 \%$ 가 우울증이 있었으며, 65 세 이상 노인의 비율은 남녀가 유사하였다. 연구참여자의 $32 \%$ 는 질병을 보유하고 있었으며, 남성 중 $31.2 \%$, 여성 중 $32.4 \%$ 로 성별에 따른 차이가 크지 않 았으며, 65 세 이상 노인의 비율은 남성이 $6.4 \%$ 높은 것 으로 나타났다.

\section{질병 유무에 따른 규칙적인 신체활동과 우울증의 관계}

질병 유무에 따른 규칙적인 신체활동 실천과 우울증의 관계는 〈Table 3〉에 제시된 바와 같이 통계적으로 유의 한 관계가 있다. 성별, 나이, 음주, 흡연, 결혼상태, 학력 그리고 체질량지수를 보정변수로 투입한 Model 2에서, 규칙적인 신체활동 실천은 일반사람 그룹에서 $33 \%$, 질 병을 가진 환자 그룹에서 $51 \%$ 의 우울증 유병률을 감소시 키는 것으로 나타났다. 특히, 두 그룹 모두 우울증 유병률 의 감소 효과가 있었지만, 질병을 가진 환자 그룹에서 규 칙적인 신체활동 실천이 우울증 유병률 감소에 더 큰 효 과가 있는 것으로 나타났다.

Table 3. Odds ratio and 95\% confidence interval between regular physical activity and depression

\begin{tabular}{|c|c|c|c|c|c|c|c|c|}
\hline & \multicolumn{4}{|c|}{ Without major chronic disease $(\mathrm{N}=1,874)$} & \multicolumn{4}{|c|}{ With major chronic disease $(\mathrm{N}=880)$} \\
\hline & $\mathrm{N}$ & $\begin{array}{l}\text { No. of } \\
\text { events } n\end{array}$ & $\begin{array}{c}\text { Model } 1 \\
\text { OR }(95 \% \text { CI) }\end{array}$ & $\begin{array}{c}\text { Model } 2 \\
\text { OR }(95 \% \mathrm{CI})\end{array}$ & $\mathrm{N}$ & $\begin{array}{l}\text { No. of } \\
\text { events } n\end{array}$ & $\begin{array}{c}\text { Model } 1 \\
\text { OR }(95 \% \text { CI })\end{array}$ & $\begin{array}{c}\text { Model } 2 \\
\text { OR }(95 \% \text { CI })\end{array}$ \\
\hline \multicolumn{9}{|c|}{$\begin{array}{l}\text { Regular physical } \\
\text { activity }\end{array}$} \\
\hline No & 1,251 & 134 & 1 (ref) & 1 (ref) & 553 & 105 & 1 (ref) & 1 (ref) \\
\hline Yes & 623 & 37 & $\begin{array}{c}.496^{* * * *} \\
(.395 \sim .622)\end{array}$ & $\begin{array}{c}.672 * * \\
(.542 \sim .834)\end{array}$ & 327 & 29 & $\begin{array}{c}.402 * * * \\
(.295 \sim .549)\end{array}$ & $\begin{array}{c}.493 * * * \\
(.368 \sim .603)\end{array}$ \\
\hline
\end{tabular}

$* * p<.01, * * * p<.001$

Major chronic disease : hypertension, hyperlipidemia, diabetes mellitus, cardiovascular disease, cerebrovascular diseases, cancer

Model 1 : not adjusted, Model 2 : adjusted for gender, age, alcohol. smoke, spousal status, education, and Body Mass Index(BMI)

Table 4. Odds ratio and 95\% confidence interval between physical activity frequency and depression

\begin{tabular}{|c|c|c|c|c|c|c|c|c|}
\hline & \multicolumn{4}{|c|}{ Without major chronic disease $(\mathrm{N}=1,874)$} & \multicolumn{4}{|c|}{ With major chronic disease $(\mathrm{N}=880)$} \\
\hline & $\mathrm{N}$ & $\begin{array}{l}\text { No. of } \\
\text { events } n\end{array}$ & $\begin{array}{c}\text { Model } 1 \\
\text { OR (95\% CI) }\end{array}$ & $\begin{array}{c}\text { Model } 2 \\
\text { OR }(95 \% \mathrm{CI})\end{array}$ & $\mathrm{N}$ & $\begin{array}{c}\text { No. of } \\
\text { events n }\end{array}$ & $\begin{array}{c}\text { Model } 1 \\
\text { OR }(95 \% \text { CI })\end{array}$ & $\begin{array}{c}\text { Model } 2 \\
\text { OR }(95 \% \mathrm{CI})\end{array}$ \\
\hline \multicolumn{9}{|c|}{$\begin{array}{l}\text { Physical activity } \\
\text { frequency / wk }\end{array}$} \\
\hline None & 1,251 & 134 & 1 (ref) & 1 (ref) & 553 & 104 & 1 (ref) & 1 (ref) \\
\hline $1 \sim 2$ & 145 & 13 & $\begin{array}{c}.867 \\
(.533 \sim 1.515)\end{array}$ & $\begin{array}{c}.913 \\
(.572 \sim 1.639)\end{array}$ & 63 & 5 & $\begin{array}{c}.427 * * \\
(.250 \sim .708)\end{array}$ & $\begin{array}{c}.496^{* *} \\
(.286 \sim .793)\end{array}$ \\
\hline$\geqq 3$ & 478 & 24 & $\begin{array}{c}.538^{* *} \\
(.355 \sim .816)\end{array}$ & $\begin{array}{c}.637^{*} \\
(.397 \sim .942)\end{array}$ & 264 & 25 & $\begin{array}{c}.466^{* *} \\
(.297 \sim .732)\end{array}$ & $\begin{array}{c}.674^{*} \\
(.365 \sim .939)\end{array}$ \\
\hline
\end{tabular}

$* p<.05, * * p<.01$

Major chronic disease : hypertension, hyperlipidemia, diabetes mellitus, cardiovascular disease, cerebrovascular diseases, cancer Model 1 : not adjusted, Model 2 : adjusted for gender, age, alcohol. smoke, spousal status, education, and Body Mass Index(BMI) 


\section{질병 유무에 따른 신체활동 빈도와 우울증의 관계}

〈Table 4〉는 질병 유무에 따른 주당 신체활동 빈도와 우울증의 관계를 나타내고 있다. 성별, 나이, 음주, 흡연, 결혼상태, 학력 그리고 체질량지수를 보정변수로 투입한 Model 2의 결과에서 주 1회 2회 신체활동은 일반사람 그룹에서 통계적으로 유의하지 않았지만, 질병을 가진 환자 그룹에서는 유병률을 $51 \%$ 감소시켰다. 또한, 주 3회 이상 신체활동은 두 그룹 모두 통계적으로 유의한 결과를 나타 냈으며, 신체활동을 하지 않은 그룹에 비해 각각 $37 \%$, $33 \%$ 의 우울증 유병률이 낮은 것으로 나타났다. 일반인은 주 3 회 이상의 신체활동이 우울증 유병률 감소에 더 큰 효과가 있었지만, 질병을 가진 환자는 신체활동을 주 1 회 $\sim 2$ 회 실시할 때 더 큰 우울증 유병률 감소 효과가 있었다.

\section{질병 유무에 따른 신체활동 시간과 우울증의 관계}

〈Table 5〉는 질병 유무에 따른 주당 신체활동 시간과 우울증의 관계를 나타내고 있다. 성별, 나이, 음주, 흡연, 결혼상태, 학력 그리고 체질량지수를 보정변수로 투입한 Model 2 에서 일반사람은 주당 신체활동이 0 분인 그룹에 비해 주 150 분 이상 300 분 미만인 그룹과 주 300 분 이상 실시한 그룹에서 각각 $43 \%, 38 \%$ 우울증 유병률이 낮았 다. 질병을 가진 환자는 주당 신체활동이 0 분인 그룹에
비해 주 150 분 미만인 그룹은 우울증 유병률이 $43 \%$ 낮 았고, 주 150 분 이상 300 분 미만인 그룹은 $52 \%$ 낮았다. 일반사람의 주 150 분 미만의 신체활동을 실시한 그룹과 질병을 가진 환자의 주 300 분 이상 신체활동을 실시한 그 룹에서는 통계적으로 유의한 결과가 나타나지 않았다.

일반사람과 질병을 가진 환자 모두 주 150 분 이상 300 분 미만의 신체활동에서 가장 큰 감소 효과가 나타났 으며, 주 300 분 미만의 신체활동에서 같은 시간의 신체활 동을 실시했을 때, 질병을 가진 환자는 일반사람에 비해 우 울증 유병률이 더 크게 감소하였다.

\section{논 의}

많은 선행연구에서 신체활동은 신체 능력의 보존 및 향상 뿐만 아니라, 정신적으로도 긍정적인 영향을 미침으 로써 심신 건강에 기여하는 것으로 알려져 있으며(Jin et al., 2019), 신체활동 및 운동이 우울증 감소에 효과가 있음을 증명하였다(Abu-Omar et al., 2004; Bhui \& Fletcher, 2000). 본 연구에서도 신체활동이 우울증 유 병률 감소에 긍정적인 영향을 미쳤으며, 이는 많은 선행 연구 결과와 일치하였다.

신체활동이 우울증에 긍정적인 영향을 가져오는 기전

Table 5. Odds ratio and 95\% confidence interval between physical activity amounts and depression

\begin{tabular}{|c|c|c|c|c|c|c|c|c|}
\hline & \multicolumn{4}{|c|}{ Without major chronic disease $(\mathrm{N}=1,874)$} & \multicolumn{4}{|c|}{ With major chronic disease $(\mathrm{N}=880)$} \\
\hline & $\mathrm{N}$ & $\begin{array}{l}\text { No. of } \\
\text { events } n\end{array}$ & $\begin{array}{c}\text { Model } 1 \\
\text { OR }(95 \% \text { CI) }\end{array}$ & $\begin{array}{c}\text { Model } 2 \\
\text { OR }(95 \% \text { CI) }\end{array}$ & $\mathrm{N}$ & $\begin{array}{c}\text { No. of } \\
\text { events } n\end{array}$ & $\begin{array}{c}\text { Model } 1 \\
\text { OR }(95 \% \text { CI })\end{array}$ & $\begin{array}{c}\text { Model } 2 \\
\text { OR }(95 \% \text { CI })\end{array}$ \\
\hline \multicolumn{9}{|l|}{$\begin{array}{l}\text { Physical activity } \\
\text { amounts / wk }\end{array}$} \\
\hline None & 1,251 & 134 & 1 (ref) & 1 (ref) & 553 & 105 & 1 (ref) & 1 (ref) \\
\hline$<150 \min$ & 72 & 6 & $\begin{array}{c}.756 \\
(.455 \sim 1.007)\end{array}$ & $\begin{array}{c}.873 \\
(.549 \sim 1.313)\end{array}$ & 33 & 4 & $\begin{array}{c}.440 * * * \\
(.289 \sim .671)\end{array}$ & $\begin{array}{c}.571^{* *} \\
(.378 \sim .814)\end{array}$ \\
\hline $\begin{array}{l}\geqq 150 \mathrm{~min} \\
\sim<300 \mathrm{~min}\end{array}$ & 225 & 14 & $\begin{array}{c}.408 * * * \\
(.287 \sim .582)\end{array}$ & $\begin{array}{c}.572 * * \\
(.387 \sim .763)\end{array}$ & 133 & 10 & $\begin{array}{c}.349^{* * *} \\
(.217 \sim .562)\end{array}$ & $\begin{array}{c}.488^{* * *} \\
(.291 \sim .649)\end{array}$ \\
\hline$\geqq 300$ min & 326 & 17 & $\begin{array}{c}.383^{* *} \\
(.216 \sim .679)\end{array}$ & $\begin{array}{c}.627^{*} \\
(.343 \sim .846)\end{array}$ & 161 & 15 & $\begin{array}{c}.427^{* *} \\
(.228 \sim .801)\end{array}$ & $\begin{array}{c}.761 \\
(.231 \sim 1.238)\end{array}$ \\
\hline
\end{tabular}

$* \mathrm{p}<.05, * * \mathrm{p}<.01, * * * \mathrm{p}<.001$

Major chronic disease : hypertension, hyperlipidemia, diabetes mellitus, cardiovascular disease, cerebrovascular diseases, cancer Model 1 : not adjusted, Model 2 : adjusted for gender, age, alcohol. smoke, spousal status, education, and Body Mass Index(BMI) 
은 다음과 같다. 첫째, 신체활동은 세로토닌(Serotonin), 도파민(Dopamine), 노르에피네프린(Norepinephrine) 같은 주요 신경전달물질의 양과 활성도를 증가시키고, 코 티졸(Cortisol)의 감소, 엔돌핀(Endorphin)의 방출 및 이용을 통해 항우울 효과를 제공한다(Ransford, 1982). 둘째, 신체활동의 항우울 효과는 뇌 유래 신경 성장인자 (Brain-derived neurotrophic factors, $\mathrm{BDNF}$ )와 관련 이 있다. 신체활동은 혈당의 수치를 감소시키고, 뇌의 혈 당 유지를 위해 간에서 케톤체를 생성한다. 이 케톤체는 해마에서 모노카복실레이트 수송체(Monocarboxylate transporter-2, Mct2) 활성화를 유도함으로써 $\mathrm{BDNF}$ 발현을 증가시키며, $\mathrm{BDNF}$ 는 우울증에 영향을 주는 뉴런 세포의 생존을 증가시켜 항우울 효과를 발생시킨다 (Albrecht et al., 2015; Newman \&Verdin, 2014). 셋 째, 자기 결정 및 자기 효능 이론에 따라 신체 활동에 참 여할 때 자신의 능력에 더 자신감을 갖고 자신을 더 잘 통 제할 수 있다고 느끼게 되기 때문에 우울증을 관리할 수 있다(Bridle et al., 2012). 마지막으로, 우울증은 심리 적 트라우마와 스트레스 자극과 깊은 연관이 있으며, 신 체활동은 스트레스 자극을 다른 측면으로 분산시키는 역 할을 수행함으로써 항우울 효과를 얻을 수 있다(Murri et al., 2018).

이러한 신체활동의 효과가 모든 그룹에서 동일하게 나 타나는 것은 아니다. 본 연구에서는 질병 유무에 따라 신 체활동과 우울증의 관계를 알아보았다. 신체활동은 질병 을 가진 환자 그룹에서 일반사람보다 우울증에 더 큰 영 향을 미쳤다. 다시 말해, 같은 빈도와 시간의 신체활동에 서 질병을 가진 환자의 우울증 유병률이 더 크게 감소하 였다.

일반사람에 비해 질병을 가진 환자는 자신의 신체적 불편으로 인해 자아효능감과 자부심이 떨어지고, 사회적 활동이 감소하기 때문에 우울증이 유발될 확률이 높다 (Husson et al., 2013). 즉, 질병을 가진 환자는 신체뿐 만 아니라 정신건강도 매우 약화된 상태인 것이다. 트레 이닝 이론에 의하면, 신체가 약한, 즉, 운동을 실시하지 않은 사람일수록 초기에 운동 효과가 급격하게 나타난다 (Cannon, 2010). 이러한 이론에 근거하여 본 연구에서 도 정신건강이 약화된 질병을 가진 환자 그룹에서 신체활 동으로 인한 우울증 유병률 감소 효과가 더 크게 나타났
으며, 적은 빈도와 시간에서도 유의하게 감소하는 것으로 나타났다. 선행연구에서도 같은 연구결과가 보고되었다. North et al.(1990)은 80편의 운동과 우울증에 관한 실 험연구를 메타 분석한 결과, 일반사람은 -0.53 , 심근경색 환자는 -0.94 의 효과 크기를 보고하고 있어, 운동 중재는 심근경색 환자그룹에서 우울증상 감소에 더 큰 효과가 있 는 것을 확인하였다.

신체활동의 양-반응 관계를 알아보기 위해 신체활동 빈도와 시간을 분류하여 분석하였다. 일반사람은 빈도가 높을수록 효과가 좋았으나, 시간에서는 주 300 분 이상의 신체활동보다 주 150 분 이상 300 분 미만의 신체활동에 서 더 큰 효과가 나타났다. 질병이 있는 환자는 주 1회 2 회, 150 분 300 분에서 가장 유병률이 낮았다. 본 연구 와 유사하게 양-반응 관계를 규명하기 위한 선행연구가 진행되었다. Dunn et al. (2005)은 일반사람을 대상으로 양-반응 관계를 연구한 결과, $\mathrm{ACSM}$ 에서 제시한 중강도 주 150 분 이상의 신체활동 가이드라인을 충족하는 그룹 에서 우울증이 더 큰 폭으로 감소하였고, 신체활동과 우 울증 유병률의 관계를 살펴본 선행연구에서는 주 150 분 이상의 신체활동이 우울증 유병률을 $27 \%$ 63\% 감소시 켰다고 보고하고 있다(Ball et at., 2009; Brown et al., 2005; Smith et al., 2010). 신체활동 빈도에 대한 선행 연구에서는 주 3회 이상의 신체활동 빈도에서 우울증 유 병률이 가장 낮았다(Bishwajit et al.,2017; Camacho et al., 1991). 질병을 가진 환자를 대상으로 실시한 선행 연구는 대부분 실험연구로 주 1회 2회, 90 분 120 분의 신체활동 중재를 실시하여 항우울증 효과가 있었음을 보 고하였다(Raatikainen et al., 2019; Abdelbasset et al., 2019). 이러한 선행연구와 본 연구의 결과를 종합해 볼 때, 일반사람과 질병을 가진 환자 모두 ACSM 신체활 동 가이드라인에서 제시하고 있는 주 150 분 이상을 충족 할 경우, 최대의 우울증 유병률 감소 효과가 나타나지만, 신체활동 빈도에서는 질병 유무에 따라 우울증 감소 효과 가 상이하다. 따라서, 우울증 유병률을 감소시키기 위한 신체활동 가이드라인을 설정할 경우, 질병 유무는 반드시 고려되어야 하는 요소이며, 대상자가 부담없이 즐겁게 수 행할 수 있는 신체활동의 시간과 빈도 설정이 필요하다.

우울증은 정신적 질병으로, 스트레스에 매우 취약하 다. 일반사람과 질병을 가진 환자 모두에게 많은 양의 신 
체활동으로 인한 스트레스는 항우울 효과를 감소시키거 나 역효과가 발생할 수 있다. 이러한 역효과를 방지하기 위해서는 스트레스를 최소로 한 즐거운 신체활동을 수행 해야 한다. 이러한 방법으로 Brand \& Ekkekakis (2018)은 운동 강도와 시간을 본인 스스로 정하고 실천하 는 것이 중요하다고 보고하고 있다. 또한, Vancampfort et al. (2015)는 신체활동 실시 동기의 측면을 강조하고 있다. 스스로에 과도한 빈도와 시간으로 인한 스트레스는 신체활동의 동기를 저해하는 요소이기 때문에, 항우울 효 과를 위해서는 빈도와 시간을 고려하기보다 개인의 선호 와 과거의 경험을 고려하여 신체활동으로 즐거움과 동기 를 찾도록 해주는 것이 중요하다. 특히, 질병을 가진 환자 는 신체활동을 실시하는 것이 특별한 도전이다. 자신의 신체적 결함으로 성공적인 수행에 대해 부정적인 견해를 가지기 때문에 신체활동을 회피한다. 이러한 경우, 달성 가능한 양의 신체활동 목표를 제시하고 실시하는 것만으 로도 우울증 유병률을 충분히 감소시킬 수 있다(Raglin \& Wilson, 2015).

본 연구는 몇 가지 제한점을 가지고 있다. 첫째, 단면 조사연구로써 신체활동과 우울증의 인과관계를 설명하 지 못하였다. 둘째, 신체활동 설문지에서 신체활동의 형 태와 강도를 포함하지 않아 어떠한 신체활동을 수행했는 지 명확히 할 수 없었다. 셋째, 연구에서 사용된 우울증 척도 검사 설문지 $(\mathrm{K}-\mathrm{CESD})$ 는 임상적인 우울증 진단 도 구가 아니기에 정확한 우울증을 진단하지 못하였다. 넷 째, 질병을 고혈압, 고지혈증, 당뇨, 심장질환, 뇌혈관질 환, 각종 암으로 한정하여 연구를 진행하여 모든 질병에 적용하기 어렵다.

이러한 제한점에도 불구하고 본 연구는 일반사람과 질 병을 가진 환자에게 우울증 유병률을 감소시킬 수 있는 신체활동의 빈도와 시간을 제시하였다는 점에서 큰 의의 가 있다.

\section{결론 및 제언}

본 연구는 대한민국 농촌 주민을 대상으로 질병 유무 에 따라 신체활동과 우울증의 관계가 차이가 있는지 알아 보는 연구를 진행하였다. 신체활동은 우울증 유병률을 감
소시키는 결과가 나타났지만, 질병 유무와 신체활동의 빈 도, 시간에 따라 영향력은 상이했다. 즉, 최대 우울증 유 병률 감소 효과는 적정 수준의 신체활동 빈도와 시간에서 나타났으며, 빈도는 질병을 가진 환자는 주 1회 2회, 일 반사람은 3회 이상에서, 시간은 일반사람과 질병을 가진 환자 모두 ACSM 신체활동 가이드라인을 충족했을 때, 가장 큰 우울증 유병률 감소 효과가 있었다. 하지만, 질병 을 가진 환자는 주 150 분 미만의 시간에서도 $43 \%$ 의 감 소 효과가 나타나고, 300 분 이상에서는 통계적으로 유의 하지 않은 결과가 나타나 300 분 미만의 신체활동이 적합 하다.

본 연구를 토대로 추후에는 신체활동과 우울증 관계에 관한 종단적 연구를 통해 인과관계를 규명하고, 다양한 집단을 대상으로 실험연구를 실시하여 신체활동의 효과 를 규명하는 연구가 필요할 것으로 생각된다. 또한, 우울 증 환자가 지속적으로 증가하고 자살이 대한민국 사망률 5 위임을 고려할 때, 우울증 예방과 치료를 위한 신체활동 가이드라인 제정이 조속히 이루어져야 할 것이다.

\section{참고문헌}

Abdelbasset WK, Alqahtani BA, Alrawaili SM, Ahmed AS, Elnegamy TE, Ibrahim AA, \& Soliman GS. (2019). Similar effects of low to moderate-intensity exercise program vs moderate-intensity continuous exercise program on depressive disorder in heart failure patients: A 12-week randomized controlled trial. Medicine(Baltimore), 98(32), e16820.

Abu-Omar K, Ruten A, \& Lehtinen V. (2004). Mental health and physical activity in the European Union. Sozial-und präventivmedizin, 49(5), 301 - 309.

Albrecht E, Norheim F, Thiede B, Holen T, Ohashi T, \& Schering L. (2015). Irisin-a myth rather than an exercise -inducible myokine. Scientific reports, 5, 8889.

Allan CL, \& Ebmeier KP. (2018). Review of treatment for late-life depression. Advances in psychiatric treatment, 19, 302-309.

Ball K, Burton N, \& Brown W. (2009). A prospective study of overweight, physical activity, and depressive symptoms in young women. Obesity, 17(1), 66-71.

Bhui K, \& Fletcher A. (2000). Common mood and anxiety states: gender differences in the protective effect of physical activity. 
Social psychiatry and psychiatric epidemiology, 35(1), 28 -

35.

Bishwajit G, O’Leary DP, Ghosh S, Yaya S, Tang SF, \& Feng ZC. (2017). Physical inactivity and self-reported depression among middle- and older-aged population in South Asia: World health survey. BMC geriatrics, 17, 100.

Brand R, \& Ekkekakis P. (2018). Affective-reflective theory of physical inactivity and exercise. German Journal of exercise and sport research, 48(1), 48 - 58.

Bridle C, Spanjers K, Patel S, Atherton NM, \& Lamb SE. (2012). Effect of exercise on depression severity in older people: systematic review and meta-analysis of randomised controlled trials. The british Journal of psychiatry, 201(3), 180-185.

Brown WJ, Ford JH, Burton NW, Marshall AL, \& Dobson AJ. (2005). Prospective study of physical activity and depressive symptoms in middle-aged women. American Journal of preventive medicine, 29(4), 265-272.

Camacho TC, Roberts RE, Lazarus NB, Kaplan GA, \&Cohen RD. (1991). Physical activity and depression: evidence from the Alamada County study. American Journal of epidemiology, 134(2), $220-231$.

Cannon J. \& Marino FE. (2010). Early-phase neuromuscular adaptations to high- and low-volume resistance training in untrained young and older women. Journal of sports sciences, 28(14), 1505 - 1514.

Cho MJ, \& Kim KH. (1993). Diagnostic validity of the CES-D (Korean version) in the assessment of DSM-III-R major depression. Journal of korean neuropsychiatric association, 32(3), 381-399.

Cipriani A, Furukawa TA, \& Salanti G. (2018). Comparative efficacy and acceptability of 21 antidepressant drugs for the acute treatment of adults with major depressive disorder: a systematic review and network meta-analysis. Psychotherapy: Access to effective treatments, 16(4), 420-429.

Cuijpers P, Turner EH, \& Mohr DC. (2014). Comparison of psychotherapies for adult depression to pill placebo control groups: a meta-analysis. Psychological medicine, 44(4), 685-695.

Dunn AL, Trivedi MH, Kampert JB, Clark CG, \& Chambliss HO. (2005). Exercise treatment for depression: Efficacy and dose response. American Journal of preventive medicine, 28(1), $1-8$.

Felipe BS, \& Brendon S. (2019). The Role of Exercise in
Preventing and Treating Depression. American college of sports medicine, 18(8), 299-304.

Husson O, Thong MS, Mols F, Smilde TJ, Creemers GJ, \& Franse LV. (2013). Information provision and patient reported outcomes in patients with metastasized colorectal cancer: results from the PROFILES registry. Journal of palliat medicine, 16(3), 281 - 288.

Isacsson G, Rich CL, Jureidini J, \& Raven M. (2010). The increased use of antidepressants has contributed to the worldwide reduction in suicide rates. The British Journal of Psychiatry, 196(6), 429-433.

Jin YG, Kim DH, Hong HR, \& Kang HS. (2019). A Long-Term Exercise Intervention Reduces Depressive Symptoms in Older Korean Women. Journal of Sports Science and Medicine, 18, 399-404.

Katon WJ. (2011). Epidemiology and treatment of depression in patients with chronic medical illness. Dialogues in clinical neuroscience, $13(1), 7$ - 23.

Kennedy GJ, Kelman HR, \& Thomas C. (1991). Persistence and remission of depressive symptoms in late life. American Journal of Psychiatry, 148, 174-178.

Mezuk B, Eaton WW, \& Albrecht S. (2008). Depression and type 2 diabetes over the lifespan: a meta-analysis. Diabetes Care, 31(12), 2383-2390.

Murri MB, Ekkekakis P, Menchetti M, Neviani F, Trevisani F, Tedeschi S, Latessa PM., Nerozzi E, Ermini G, Zocchi D, Squatrito S, Toni G, Cabassi A, Neri M, Zanetidou S, \& Amore M.. (2018). Physical exercise for late-life depression: effects on symptom dimensions and time course. Journal of Affective Disorders, 230, 65-70.

Nan H, Lee PH, \& McDowell I. (2012). Depressive symptoms in people with chronic physical conditions: prevalence and risk factors in a Hong Kong community sample. BMC Psychiatry, 12, 198.

Newman JC, \&Verdin E. (2014). $\beta$-hydroxybutyrate: much more than a metabolite. Diabetes research and clinical practice, 106(2), 173-181.

North TC, McCullagh P, \& Tran ZV. (1990). Effects of exercise on depression. Exercise and Sport Sciences Reviews, 18(1), 379 -415 .

Peterson JC, Charlson ME, Wells MT, \& Altemus M. (2014). Depression, Coronary Artery Disease, and Physical Activity: How Much Exercise Is Enough?. Clinical Therapeutics, 
36(11), 1518-1530.

Raatikainen I, Mäntyselkä P, Vanhala M, Heinonen A, Koponen H, Kautiainen H, \& Korniloff K. (2019). Leisure time physical activity and its relation to psychiatric comorbidities in depression: Findings from Finnish Depression and Metabolic Syndrome in Adults (FDMSA) study. Journal of Affective Disorders, 259, 150-153.

Raglin JS, \& Wilson GS. (2005). Exercise adherence and prescription for special populations. Exercise testing and exercise prescription for special cases: Theoretical basis and clinical application 3rd edition, JS Skinner. Lippincott, Baltimore:Williams \& Wilkins, 124 - 133.

Radloff LS. (1977). The CES-D Scale: A Self-Report Depression Scale for Research in the General Population. Applied Psychological Measurement, 1(3), 385 - 401.

Ransford CA. (1982). Arole for amines in the antidepressant effect of exercise: a review. Medicine and Science in Sports and Exercise, 14(1), 1-10.

Smith T, Masaki K, Fong K, Abbott R, Ross G, Petrovitch H, Blanchette P, \& White L. (2010). Effect of walking distance on 8-year incident depressive symptoms in elderly men with and without chronic disease: the Honolulu-Asia aging study. Journal of the American Geriatrics Society, 58(8), 1447-1452. Statistics Korea. (2019). Cause of death statistics 2018.
Underwood M., Lamb SE, Eldridge S, Sheehan B, Slowther AM, Spencer A., Thorogood M, Atherton N, Bremner SA, Devine A, Diaz-Ordaz K, Ellard DR, Potter R, Spanjers K, \& Taylor SJ. (2013). Exercise for depression in elderly residents of care homes: a cluster-randomised controlled trial. The Lancet, 382(9886), 41-49.

Vancampfort D, Stubbs B, \& Venigalla SK. (2015). Adopting and maintaining physical activity behaviors in people with severe mental illness: the importance of autonomous motivation. Preventive medicine, 81, 216 - 220.

Walker ER, McGee RE, \& Druss BG. (2015). Mortality in mental disorders and global disease burden implications: Asystematic review and meta-analysis. JAMA Psychiatry. 72(4), 334 - 341.

Wang R, Bishwajit G, Zhou Y, Wu X, Feng D, Tang S, Chen Z, Shaw I, Wu T, Song HX, Fu Q, \& Feng ZC. (2019). Intensity, frequency, duration, and volume of physical activity and its association with risk of depression in middle- and older-aged Chinese: Evidence from the China Health and Retirement Longitudinal Study, 2015. PLOS ONE, 14(8), e0221430.

Williams P, \& Lord SR. (1997). Effects of group exercise on cognitive functioning and mood in older women. Australian and New Zealand Journal of Public Health, 21(1), 45-52. 


\section{0세 이상 중·노년의 질병 유무에 따른 신체활동과 우울증의 관계 \\ 김정운 ${ }^{1}$, 김준식 ${ }^{1}$, 임정준 ${ }^{1}$, 김연수 $^{2}$, 이온 $^{3}$, 최보율 $^{4}$, 김미경 ${ }^{4}$ \\ ${ }^{1}$ 서울대학교, 박사과정 \\ ${ }^{2}$ 서울대학교, 교수 \\ 3한국스포츠정책과학원 연구위원 \\ ${ }^{4}$ 한양대학교, 교수}

[목적〕 본 연구의 목적은 질병 유무에 따른 신체활동과 우울증의 관계를 알아보는데 있다. 〔방법] 농촌기반 코호트 사업에 참여한 40세 이상 남녀 2,754명 (남자 1,025명, 여자 1,729명)을 대상으로 설문조사와 기초 평가를 실시하였다. 설문조사는 신체활동 설문과 우울증 척도 검사 $(\mathrm{K}-\mathrm{CESD})$, 질병유무 설문을 실시하였으 며, 기초평가는 신장, 체중, 체지방률 등을 측정하였다. 데이터는 로지스틱 회귀분석을 통해 신체활동과 우울 증 유병률의 관계를 분석하였다. 〔결과〕 첫째, 일반사람과 질병을 가진 환자에서 신체활동은 우울증 유병률을 각각 $33 \%, 51 \%$ 감소시켰다. 둘째, 주 1회 2회의 신체활동은 질병을 가진 환자의 우울증 유병률을 $51 \%$ 감소시키며, 3 회 이상은 일반사람 $37 \%$, 질병을 가진 환자 $33 \%$ 의 우울증 유병률을 감소시켰다. 셋째, 주 150 분 미만의 신체활동은 질병을 가진 환자의 우울증 유병률을 $43 \%$ 감소시켰으며, 주 150 분 이상 300 분 미만의 신체활동은 일반사람 $43 \%$, 질병을 가진 환자 $52 \%$ 의 유병률을 감소시켰다. 주 300 분 이상의 신체활 동은 일반사람에서 $38 \%$ 의 우울증 유병률 감소 효과가 있었다. 〔결론〕 결론적으로, 우울증 유병률을 최대로 감소시키기 위해서는 ACSM 가이드라인에서 제시하고 있는 신체활동 수준이 적합하다. 또한, 질병을 가진 환자는 일반사람보다 적은 빈도와 양의 신체활동만으로도 효과를 볼 수 있음을 알 수 있었다.

주요어: 신체활동, 우울증, 질병 